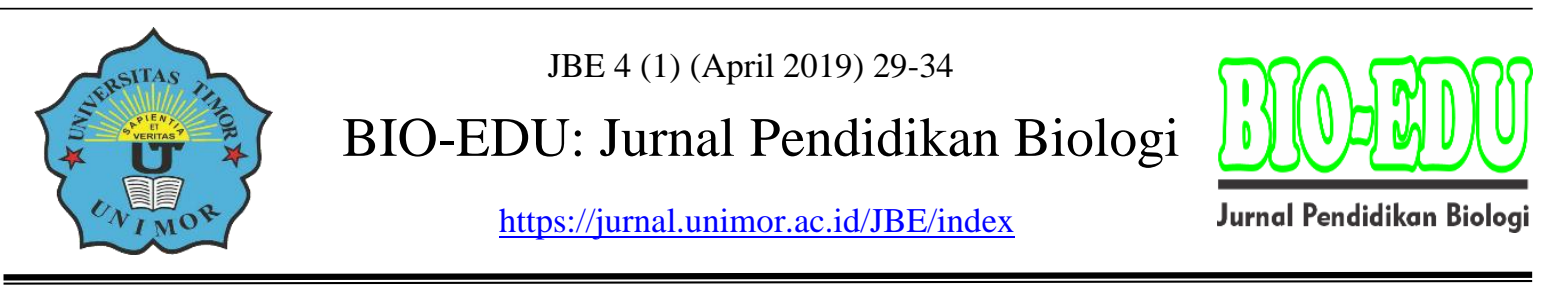

\title{
Analisis Penggunaan Sumber Belajar pada Materi Ekosistem Darat di SMA N Insana Barat dan SMK St. Agustinus Kefamenanu
}

\author{
Feliksitas Angel Masing \\ Program Studi Pendidikan Biologi, Universitas Timor \\ Email: feliksitasm@gmail.com
}

DOI: $\underline{\text { https://doi.org/10.32938/jbe.v4i1.344 }}$

\begin{abstract}
Abstrak
Penelitian ini bertujuan untuk mengetahui: (1) sumber belajar yang digunakan dalam pembelajaran Biologi materi ekosistem darat di SMAN Insana Barat, dan (2) sumber belajar yang digunakan dalam pembelajaran Biologi materi ekosistem darat di SMK St. Agustinus Kefamenanu. Penelitian ini merupakan jenis penelitian survei. Populasi penelitian adalah guru biologi di SMA Insana barat dan SMK St. Agustinus Kefamenanu. Penelitian ini dilaksanakan pada bulan Januari-Maret 2019. Teknik pengumpulan data menggunakan lembar angket sumber belajar ekosistem darat. Teknik analisis data menggunakan statistik deskriptif kualitatif. Hasil penelitian menunjukkan bahwa: (1) sumber belajar yang digunakan dalam pembelajaran Biologi materi ekosistem darat di SMAN Insana Barat terdiri dari objek langsung yaitu sebagian besar berupa ekosistem buatan sementara objek tidak langsung sebagian besar disajikan dalam buku pelajaran, lks, dan modul cetak. Untuk sumber pembelajaran berupa E-modul dan internet serta sumber belajar lainnya, belum digunakan oleh SMAN Insana Barat. Hal ini disebabkan ketersediaan wifi di sekolah tidak memadai. (2) Sumber belajar yang digunakan dalam pembelajaran Biologi materi ekosistem darat di SMK St. Agustinus Kefamenanu terdiri dari objek langsung yaitu sebagian besar berupa ekosistem buatan sementara objek tidak langsung sebagian besar disajikan dalam buku pelajaran, lks, dan modul cetak. Untuk sumber pembelajaran berupa E-modul dan internet serta sumber belajar lainnya, belum digunakan oleh guru dan peserta didik SMAN Insana Barat dan SMK St. Agustinus Kefamenanu Nusa Tenggara Timur. Hal ini disebabkan ketersediaan wifi di sekolah tidak memadai.
\end{abstract}

Kata kunci: sumber belajar, ekosistem darat

\begin{abstract}
This study aims to know: (1) learning resources used in the learning of terrestrial ecosystem biology material in SMAN Insana Barat School, and (2) learning resources used in the learning of terrestrial ecosystem biology material at St. Augustine School Kefamenanu. This research is a type of survey research. The study population was biology teachers at SMAN Insana Barat School and St. Augustine School Kefamenanu. This research was conducted in January-March 2019. Data collection techniques used questionnaires on land ecosystem learning resources. Data analysis techniques used qualitative descriptive statistics. The results of the study show that: (1) the learning resources used in learning Biology on terrestrial ecosystems in SMAN Insana Barat School consist of direct objects, most of which are artificial ecosystems while indirect objects are mostly presented in textbooks, textbooks, and print modules. For learning resources in the form of E-modules and the internet and other learning resources, they have not been used by SMAN Insana Barat. This is because the availability of wifi in schools is inadequate. (2) Learning resources used in learning biology of terrestrial
\end{abstract}


ecosystems at St. Augustine School Kefamenanu.consists of direct objects which are mostly in the form of artificial ecosystems while indirect objects are mostly presented in textbooks, textbooks, and printed modules. For learning resources in the form of E-modules and internet as well as other learning resources, it has not been used by the teachers and student from SMAN Insana Barat School and St. Augustine School Kefamenanu East Nusa Tenggara. This is because the availability of wifi in schools is inadequate.

Keywords: learning resources, terrestrial ecosystem

\section{PENDAHULUAN}

Sekolah merupakan tempat berlangsungnya proses pembelajaran formal. Proses pembelajaran di sekolah saat ini telah mengalami perubahan seiring terjadinya perubahan kurikulum dari masa ke masa. Kurikulum 2013 mengubah pembelajaran dari teacher centered ke student centered sehingga peserta didik akan terlibat aktif dan guru sebagai fasilitator. Proses pembelajaran ini melibatkan subjek utama yaitu guru dan peserta didik beserta komponen-komponen pembelajaran yang mendukung. Mengingat definisi pembelajaran menurut UU SISDIKNAS No. 20 Tahun 2003 adalah proses interaksi peserta didik dengan pendidik dan sumber belajar pada suatu lingkungan belajar. Dengan demikian dalam suatu proses pembelajaran ada interaksi antara guru dan peserta didik dengan sumber belajar.

Sumber belajar adalah segala sesuatu yang digunakan untuk mendapatkan pengetahuan dalam suatu proses pembelajaran. Menurut Zain \& Djamarah (1997 : 139), segala sesuatu baik yang sengaja dirancang (by design) maupun yang telah tersedia (by utilization) yang dapat dimanfaatkan baik secara sendiri-sendiri maupun bersama-sama untuk membuat atau membantu peserta didik belajar disebut sumber belajar. Permendikbud No. 65 Tahun 2013 menjelaskan jenis-jenis sumber belajar yang dapat digunakan dalam pembelajaran diantaranya, media cetak seperti buku, majalah, artikel dan saat ini berkembang pula berbagai media elektronik moderen, selain media cetak dan elektronik menggunakan alam sekitar sebagai sumber belajar.

Adapun menurut Siregar (2010:128), jenis-jenis sumber belajar adalah sebagai berikut: (1) Pesan (message) : informasi yang disampaikan dalam bentuk ide, makna, dan fakta, (2) Manusia (people): orang-orang yang bertindak sebagai penyimpan, pengolah dan penyalur pesan, (3) bahan media software (materials): perangkat lunak yang biasanya berisi pesan, (4) peralatan hardware (device): perangkat keras yang digunakan untuk menyampaikan pesan yang terdapat dalam bahan, (5) teknik (technique): prosedur atau langkah-langkah tertentu dalam menggunakan bahan, peralatan, lingkungan, dan orang untuk menyampaikan pesan, dan yang terakhir (6) latar (setting): lingkungan dimana pesan itu diterima oleh pembelajar.

Berdasarkan jenis bahan ajar, maka pada umumnya sumber belajar dapat berasal dari dalam maupun luar kelas. Sumber belajar yang berasal dari dalam kelas seperti guru, buku cetak, modul, dan sebagainya, sedangkan yang berasal dari luar kelas berupa lingkungan alam sekitar. Lingkungan alam sekitar yang dapat dijadikan sumber belajar yaitu berupa materi lokal khususnya ekosistem darat yang merupakan salah satu materi yang disajikan pada proses pembelajaran di sekolah. Mengingat pentingnya pemanfaatan sumber belajar dalam proses pembelajaran, maka diperlukan pendataan sumber belajar untuk materi ekosistem darat pada SMAN Insana Barat dan SMK St. Agustinus Kefamenanu berdasarkan

30|Masing/JBE 4(1) (April2 2019 ) $29-34$ 
observasi sebelumnya bahwa belum ada pendataan sumber belajar sebelumnya pada sekolah tersebut.

\section{METODE}

Lokasi penelitian di 2 (dua) sekolah yaitu SMAN Insana Barat dan SMK St. Agustinus Kefamenanu pada bulan Januari - Maret 2019. Desain pelaksanaan penelitian ini adalah penelitian survei yakni dengan metode penyebaran angket. Subjek yang akan dilibatkan dalam penelitian adalah guru biologi SMAN Insana Barat dan SMK St. Agustinus Kefamenanu.

Metode pengumpulan pada penelitian ini meliputi metode observasi, wawancara dan pengisian lembar angket. Data yang terkumpulkan dianalisis dengan menggunakan teknik statistik deskriptif kualitatif.

\section{HASIL DAN PEMBAHASAN}

\section{Hasil}

Hasil penelitian yang dilaksanakan pada SMAN Insana Barat dan SMK St. Agustinus Kefamenanu Nusa Tenggara Timur dapat dilihat pada tabel berikut :

Tabel 1. Penyajian Fakta dengan memanfaatkan objek Lokal Ekosistem Darat yang Berupa Objek Langsung pada SMAN Insana Barat dan SMK St. Agustinus Kefamenanu Nusa Tenggara Timur yang Berkaitan dengan Pokok Bahasan Ekosistem dan Komponen Penyusunannya

\begin{tabular}{|c|c|c|c|c|c|}
\hline \multirow[b]{2}{*}{ Objek lokal } & \multirow[b]{2}{*}{ Contoh } & \multicolumn{2}{|c|}{ Pernah disajikan } & \multicolumn{2}{|c|}{ Objek langsung } \\
\hline & & pernah & belum & $\begin{array}{l}\text { Tersedia di } \\
\text { Lingkungan }\end{array}$ & Tdk tersedia \\
\hline $\begin{array}{c}\text { Ekosise } \\
\text { alami }\end{array}$ & & & & & \\
\hline a. Hutan & Hutan hujan tropis & 1 & 1 & 0 & 2 \\
\hline & Hutan dataran rendah & 0 & 2 & 0 & 2 \\
\hline b. Karst & Gua & 0 & 2 & 0 & 2 \\
\hline & Bukit kapur & 0 & 2 & 0 & 2 \\
\hline c. Gunung/ & Gunung berapi aktif & 0 & 2 & 0 & 2 \\
\hline & Gunung berapi pasif & 0 & 2 & 0 & 2 \\
\hline $\begin{array}{l}\text { Ekosistem } \\
\text { Buatan }\end{array}$ & & & & & \\
\hline a.Pekarangan & $\begin{array}{c}\text { Pekarangan dengan tanaman } \\
\text { berbuah }\end{array}$ & 2 & 0 & 2 & 0 \\
\hline & $\begin{array}{c}\text { Pekarangan dengan tanaman } \\
\text { berbunga }\end{array}$ & 2 & 0 & 2 & 0 \\
\hline & Pekarangan dengan tanaman & 2 & 0 & 2 & 0 \\
\hline
\end{tabular}

31|Masing/JBE 4(1) (April 2019 ) $29-34$ 


\begin{tabular}{|c|c|c|c|c|c|}
\hline & sayuran & & & & \\
\hline & $\begin{array}{c}\text { Pekarangan dengan tanaman } \\
\text { campuran }\end{array}$ & 2 & 0 & 2 & 0 \\
\hline \multirow[t]{3}{*}{ b.Kebun } & Kebun kopi & 0 & 2 & 0 & 2 \\
\hline & Kebun pisang & 2 & 0 & 2 & 0 \\
\hline & Kebun kelapa & 2 & 0 & 2 & 0 \\
\hline \multirow[t]{2}{*}{ c.Ladang } & Ladang kobis & 0 & 2 & 0 & 2 \\
\hline & Ladang ketela & 2 & 0 & 2 & 0 \\
\hline \multirow[t]{6}{*}{ d.Permukiman } & Permukiman desa & 2 & 0 & 2 & 0 \\
\hline & $\begin{array}{c}\text { Permukiman perbatasan } \\
\text { desa-kota }\end{array}$ & 2 & 0 & 2 & 0 \\
\hline & $\begin{array}{c}\text { Permukiman kota perumahan } \\
\text { elite }\end{array}$ & 0 & 2 & 0 & 2 \\
\hline & $\begin{array}{l}\text { Permukiman kota perumahan } \\
\text { biasa }\end{array}$ & 2 & 0 & 2 & 0 \\
\hline & $\begin{array}{l}\text { Permukiman kota } \\
\text { perkampungan }\end{array}$ & 0 & 2 & 0 & 2 \\
\hline & $\begin{array}{l}\text { Permukiman kota kawasan } \\
\text { kumuh }\end{array}$ & 0 & 2 & 0 & 2 \\
\hline \multirow[t]{2}{*}{ e.Hutan buatan } & Tegakan jati & 2 & 0 & 2 & 0 \\
\hline & Tegakan Albazia (sengon) & 0 & 2 & 0 & 2 \\
\hline
\end{tabular}

Tabel 2. Ringkasan Penggunaan Sumber Belajar

\begin{tabular}{|c|c|c|c|c|c|c|}
\hline \multirow{2}{*}{ No } & \multirow{2}{*}{$\begin{array}{c}\text { Nama } \\
\text { Sekolah }\end{array}$} & $\begin{array}{c}\text { Buku } \\
\text { teks }\end{array}$ & LKS & $\begin{array}{c}\text { Modul } \\
\text { Buku }\end{array}$ & $\begin{array}{c}\text { E- } \\
\text { Modul }\end{array}$ & $\begin{array}{c}\text { Lain-lain } \\
\text { (internet } \\
\text { dll) }\end{array}$ \\
\cline { 3 - 7 } 1 & $\begin{array}{c}\text { SMAN } \\
\text { Insana Barat }\end{array}$ & $\sqrt{ }$ & $\sqrt{ }$ & $\sqrt{ }$ & - & - \\
\hline 2 & $\begin{array}{c}\text { SMK St. } \\
\text { Agustinus } \\
\text { Kefamenanu }\end{array}$ & $\sqrt{ }$ & $\sqrt{ }$ & - & - & - \\
\hline & Total & 2 & 2 & 1 & 0 & 0 \\
\hline
\end{tabular}

Keterangan :

$$
\begin{array}{ll}
\sqrt{ } & =\text { Pernah digunakan } \\
- & =\text { Belum pernah digunakan }
\end{array}
$$




\section{Pembahasan}

Berdasarkan data Tabel 1 penyajian fakta dengan memanfaatkan objek lokal yang berupa objek langsung pada SMAN Insana Barat dan SMK St. Agustinus Kefamenanu Nusa Tenggara Timur yang berkaitan dengan pokok bahasan ekosistem darat menunjukkan bahwa ekosistem buatan berupa ekosistem pekarangan, kebun, ladang, pemukiman, dan hutan jati merupakan fakta yang paling banyak dipelajari dengan jumlah persentasi $50 \%$. Hal ini dikarenakan kondisi iklim Kabupaten Kefamenanu termasuk dalam iklim lahan kering sehingga komponen ekosistem darat yang mudah ditemui dan dipelajari.

Penyajian data pada Tabel 2 di atas juga dapat dilihat bahwa berbagai fakta dalam ekosistem tidak hanya disajikan melalui objek langsung. Terlihat pada tabel 2, penyajian fakta dengan memanfaatkan objek lokal disajikan menggunakan objek tidak langsung. Objek tidak langsung yang digunakan dalam menemukan berbagai fakta sebagian besar disajikan dalam buku pelajaran, lks, dan modul cetak. Untuk sumber pembelajaran berupa E-modul dan internet serta sumber belajar lainnya, belum digunakan oleh SMAN Insana Barat dan SMK St. Agustinus Kefamenanu Nusa Tenggara Timur. Hal ini disebabkan ketersediaan wifi kedua sekolah tidak memadai. Penggunaan sumber belajar sesuai hakikatnya yakni dimanfaatkan guna kepentingan proses belajar mengajar. Baik secara langsung maupun tidak langsung, sebagian maupun keseluruhan (Sudjana, 2007: 76). Hal ini dikarenakan sumber belajar adalah suatu sistem yang terdiri dari sekumpulan bahan atau situasi yang diciptakan dengan sengaja dan dibuat agar memungkinkan peserta didik belajar secara individual (Warsita, 2008: 209). Sementara itu jenis sumber belajar yang dapat digunakan dalam pembelajaran diantaranya, media cetak seperti buku, majalah, artikel dan saat ini berkembang pula berbagai media elektronik moderen, selain media cetak dan elektronik menggunakan alam sekitar sebagai sumber belajar dapat menjadi alternatif (Permendikbud No. 65, 2013).

\section{KESIMPULAN DAN SARAN}

\section{Kesimpulan}

Kesimpulan dari penelitian ini adalah :

1. Sumber belajar yang digunakan dalam pembelajaran Biologi materi ekosistem darat di SMAN Insana Barat terdiri dari objek langsung yaitu sebagian besar berupa ekosistem buatan sementara objek tidak langsung sebagian besar disajikan dalam buku pelajaran, lks, dan modul cetak. Untuk sumber pembelajaran berupa E-modul dan internet serta sumber belajar lainnya, belum digunakan oleh SMAN Insana Barat. Hal ini disebabkan ketersediaan wifi di sekolah tidak memadai.

2. Sumber belajar yang digunakan dalam pembelajaran Biologi materi ekosistem darat di SMK St. Agustinus Kefamenanu terdiri dari objek langsung yaitu sebagian besar berupa ekosistem buatan sementara objek tidak langsung sebagian besar disajikan dalam buku pelajaran, lks, dan modul cetak. Untuk sumber pembelajaran berupa E-modul dan internet serta sumber belajar lainnya, belum digunakan oleh SMK St. Agustinus

Kefamenanu Nusa Tenggara Timur. Hal ini disebabkan ketersediaan wifi di sekolah tidak memadai. 


\section{Saran}

Penelitian ini dapat dikembangkan dengan melibatkan subjek yang lebih banyak di seluruh Kabupaten Kefamenanu sehingga akan didapatkan data penggunaan sumber belajar yang sering digunakan maupun yang belum pernah digunakan. Dari data tersebut dapat dilanjutkan dengan mengembangkan salah satu sumber belajar untuk dapat digunakan dalam pembelajaran di sekolah.

\section{DAFTAR RUJUKAN}

Adipurnomo, H. 2006. Sumber dan Media Pembelajaran. Malang: Departemen Pendidikan Nasional, Direktorat Jenderal Peningkatan Mutu Pendidikan dan Tenaga Kependidikan, Pusat Pengembangan Penataran Guru IPS dan PMP Malang.

Djamarah, Syaiful Bahri, Azwan Zain.2002. Strategi Belajar Mengajar. Jakarta: Rineka Cipta.

Permendikbud No. 65. 2013. Standar Proses Pendidikan Dasar dan Menengah. Jakarta: Menteri Pendidikan dan Kebudayaan Republik Indonesia.

Siregar, Eveline. 2010. Teori Belajr dan Pembelajaran. Bogor: Ghalia Indonesia

Sudjana, Nana, dan Ahmad Rivai.2007. Teknologi Pengajaran. Bandung: Sinar Baru Algesindo.

Undang-Undang Sistem Pendidikan Nasional No 20 Tahun 2003. Diakses tanggal 8 Mei 2019 jam 10.30 WITA.

Warsita, Bambang. 2008. Teknologi Pembelajaran Landasan dan Aplikasinya. Jakarta: Rineka Cipta.

Yunanto, Sri Joko. 2005. Sumber Belajar Anak Cerdas. Jakarta: Grasindo. 